\title{
Ponta Grossa and Castro zones in Paraná talc district, Brazil, ore properties and mineral industry
}

\author{
ANTONIO CARLOS GONDIM ${ }^{1}$; LUCIANO CORDEIRO DE LOYOLA ${ }^{2}$ \\ ${ }^{1}$ Federal University of Paraná, Marechal Mallet 185/401, 80540-230 Curitiba - PR - Brazil \\ gondim@ufpr.br \\ ${ }^{2}$ Minerais do Paraná S/A, MINEROPAR, Rua dos Dominicanos, 197, 82540-140 - Curitiba - PR - Brazil \\ luciano@pr.gov.br
}

(Received October 2002 Accepted December 2002)

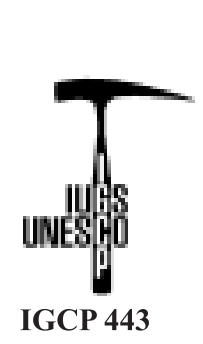

\begin{abstract}
Talc deposits of Paraná district occur as layers, lenses, veins and irregular bodies. The country rocks are dolomite marbles of the late proterozoic Itaiacoca Group. The talc ores are generally in situ, formed by metamorphic and hydrothermal processes, but there are some deposits that present concentrations of alloctone materials. These materials are partially remobilized by carstic dissolution and/or by colluvionar transport.

Talc ores differ due their chemical composition, morphology, associated minerals, whiteness and some other properties. The talc minerals in the district of Paraná can be unctuous and not unctuous, platy and powdery, sparry and micro-crystalline and some form massive and disseminated ore deposits.

The Southern zone or Ponta Grossa zone exhibits a talc ore more lamellar, platy, unctuous, softness and more varied associated minerals than the ore situated in Northern zone or Castro zone in which the talc is more powder in natural way.

There is one deposit in the São José mine that belongs to the Ponta Grossa zone, that is an exception comparing with the other deposits in terms of its presented characteristics.

The parameters that govern the specific nature of each commercial talc grade as well as its use in industrial applications including the polypropylene manufacturing are discussed in this paper.
\end{abstract}

Key words: talc, district zoning, ore properties, use, mineral industry.

\section{Introduction}

The Paraná talc district is the most important in Brazil in terms of annual production of talc. This district produced in 2000, an amount of $144,000 \mathrm{t}$ of talc, corresponding to $41 \%$ of the Brazilian production.

This district can be divided in two zones, Ponta Grossa and Castro. Each of them exhibit different characteristics of the talc ore, and that is what is being analyzed in this paper. These characteristics are very important for the different uses of talc, specially for industrial uses, like polypropylene, paper and rubber production.

Talc deposits of the Paraná district occur as layers, lenses, veins and irregular bodies. The country rocks are dolomite marbles of the Itaiacoca Group. The talc ores are generally in situ, formed by metamorphic and hydrothermal processes, but there are some deposits that present concentrations of alloctone materials. These materials are partially remobilized by carstic dissolution and/or by colluvionar transportation (Gondim 2001).

The Itaiacoca group is formed by dolomite marbles, quartzites, phyllites, and acid and basic metavolcanic rocks. These rocks represent a meta-volcanosedimentary complex related to the continental rifting during the lateproterozoic. The geological evolution of the region was described and discussed in Lima (1993), Reis Neto (1994) Ribas et al. (1999) and Gondim (2000 a,b).

The Paraná talc district has approximately 40 mines. Of these 16 are presentely in activity (10 in Castro zone and 06 in Ponta Grossa zone). The Castro zone is situated 
in the northern portion of the Paraná talc district and it has an area of $55 \mathrm{~km}^{2}$. The second zone analyzed here, is called Ponta Grossa. It has an area of $53 \mathrm{~km}^{2}$ and inside it there is a special deposit nominated São José that presents different characteristics comparing with the other deposits. The localization of the Paraná talc district and their zones are represented in Figure 1.

Talc ores differ due their chemical composition, morphology, associated minerals, whiteness and other properties. The talc minerals in the Paraná district are unctuous and not unctuous, platy and powdery, sparry and micro-crystalline, and form massive and disseminated ore deposits.

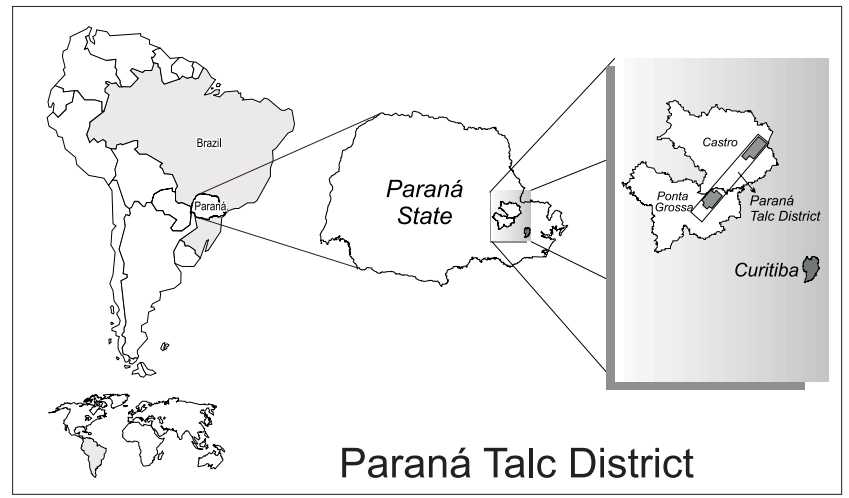

Fig. 1. The Paraná talc district, Brazil

The ore is constituted by talc accompanied by some minerals like quartz, dolomite, calcite, tremolite, chlorite, sericite, montmorillonite, caulinite, and pyrite.

Gondim (2000a) attributed two types of talc mineralization processes in the deposits of the Paraná talc district:

1. Regional dynamo-thermal metamorphism (orogenic metamorphism).

\section{Hydrothermalism.}

In the first type, the talc deposits result from the metasomatic process of the dolomite during the lateproterozoic orogenic metamorphism.

In the second type, the talc is formed by metasomatic process of the dolomite marbles, under the effect of hydrothermal fluids that carried Si and others elements. The hydrothermal system occurred during the granite emplacement in the Eo-Paleozoic (see Figure 2 and 3).

There are three types of talc deposits in Paraná talc district:
1. Talc deposits constituted by methamorphic mineralization.

2. Talc deposits constituted by hydrothermal mineralization.

3. Talc deposits with both types of mineralizations.

The talc mineralization was mainly formed by the reactions:

$$
\begin{aligned}
& \left.3 \mathrm{CaMg} \mathrm{CO}_{3}\right)_{2}+4 \mathrm{SiO}_{2}+\mathrm{H}_{2} \mathrm{O} \rightleftharpoons \\
& \mathrm{Mg}_{3}(\mathrm{OH})_{2} \mathrm{Si}_{4} \mathrm{O}_{10}+3 \mathrm{CaCO}_{3}+3 \mathrm{CO}_{2} \\
& 2 \mathrm{CaMg}\left(\mathrm{CO}_{3}\right)_{2}+\mathrm{n} \mathrm{Mg}+4 \mathrm{SiO}_{2}+\mathrm{H}_{2} \mathrm{O} \rightleftharpoons \\
& \mathrm{Mg}_{3}(\mathrm{OH})_{2} \mathrm{Si}_{4} \mathrm{O}_{10}+2 \mathrm{HCO}_{3}+2 \mathrm{CO}_{2}+2 \mathrm{Ca}
\end{aligned}
$$

The first equation took place in the São José deposit, which exhibits calcite in equilibrium with talc.

The second reaction was a common process in several deposits, it was theoretically proposed by Piniazkiewicz (1984) to establish the equalization of the system, adding magnesium in order to offset an otherwise $32 \%$ in volume reduction. The source of the fluids could be evaporitic brines, similar to the model proposed by Prochaska (2000) to talc and magnesite deposits of Austria.

The talc deposits in Paraná occur as irregular bodies along shear bedding-planes in dolomite marbles, related with regional NE faults. The morphologic controls are dolerite dykes (direction NW, vertical dip) and quartzites (direction NE, sub vertical dip). Being these dykes and quartzites bodies more weathering resistant than the dolomite marbles they protect the talc bodies against erosion, Gondim (2001).

The controls of the talc deposits are:

a) Lithologic control: dolomite marbles;

b) Structural control: NE fault system;

c) Morphologic control: dykes and quartzites bodies.

\section{Talc Properties in Castro and Ponta Grossa Zones}

As mentioned before, the talc of the Itaiacoca Group results from the transformation of carbonates (dolomite) in the presence of silica. The carbonates fix in-situ the magnesium needed to form the talc minerals, whereas the silica is provided by brine percolation during metamorphism or later during the hydrothermal system. This reaction results in a talc ore which, depending on the composition of the parent rocks, it is either mineralogically pure or sometimes it is associated with other minerals. 


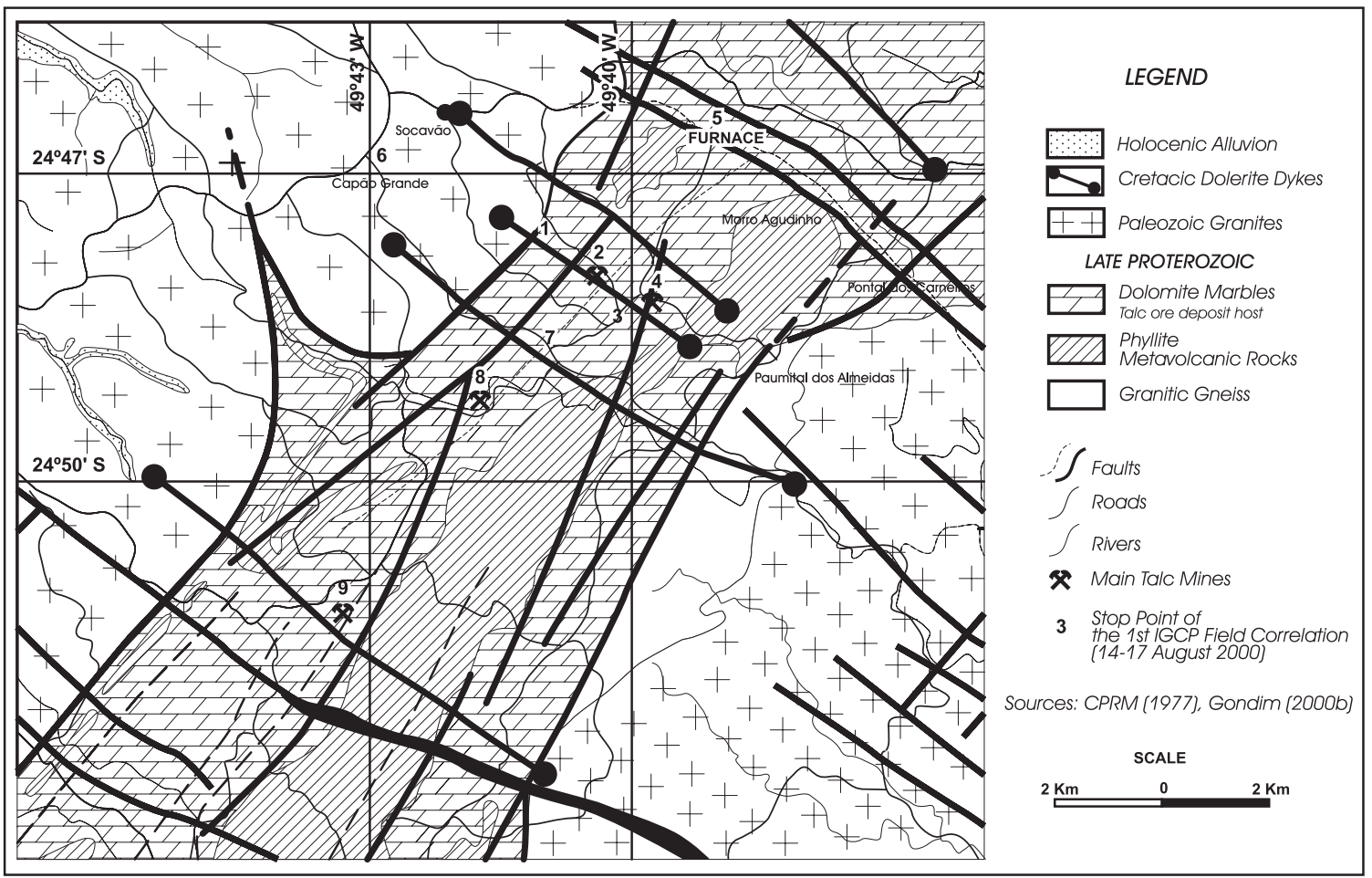

Fig. 2. Geological map of the Paraná talc district - Castro zone.

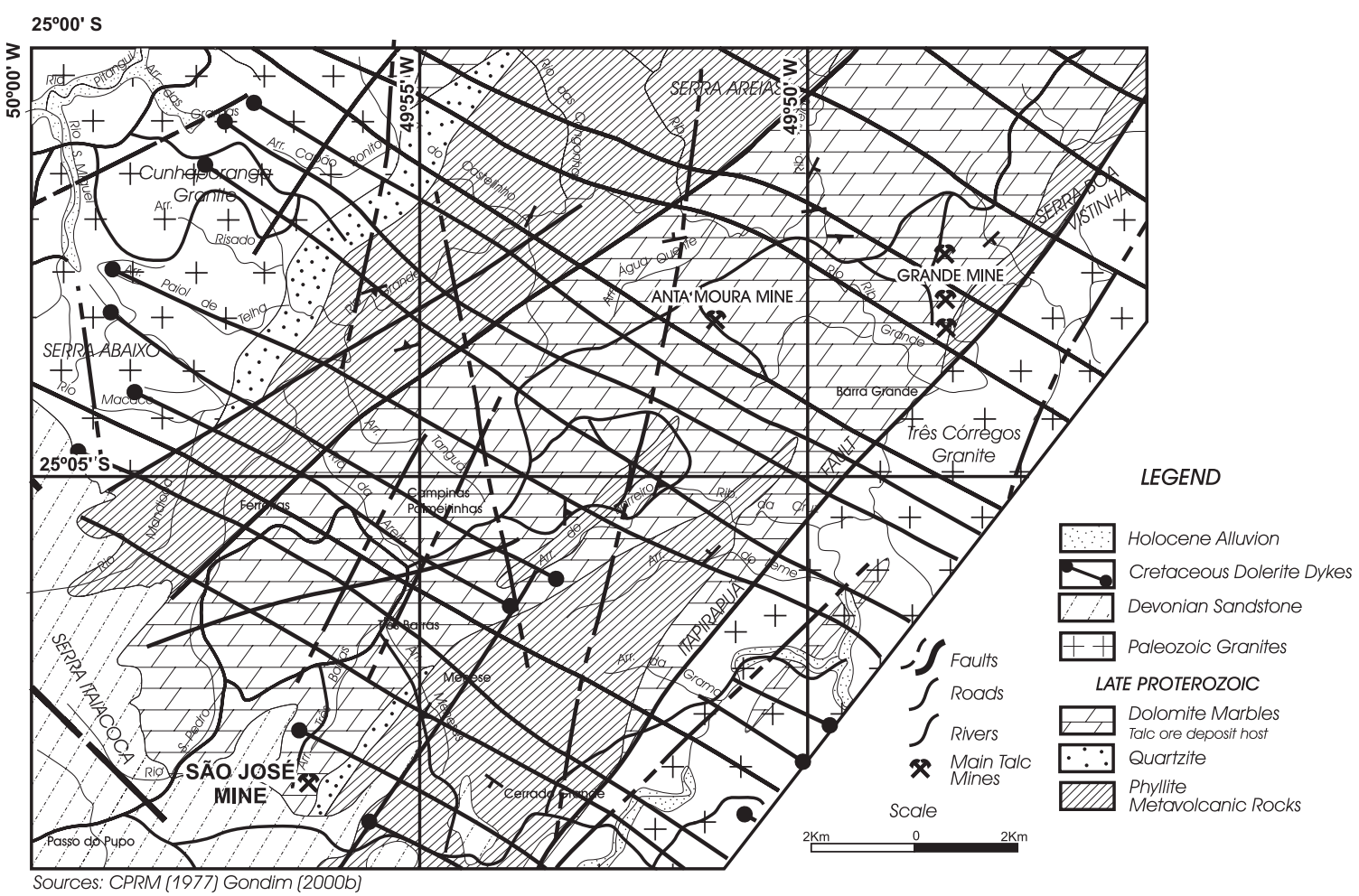

Fig. 3. Geological map of the Paraná talc district - Ponta Grossa zone. 
In the Paraná district the talc ores are chiefly white, light green, light yellow and pink. There are also dolomite marbles with disseminated talc minerals. This last type of talc is mainly used in the ceramic and paint industries.

The talc in this district has important variations along the two zones and within the individual deposits: differences on associated minerals, platyness, softness and density.

Loyola (1987) worked with 55 samples and identified several types of talc ore mined in the Paraná talc district. The minerals associated with the talc can be identified by using $\mathrm{X}$-ray and chemical analyses. The synthesis of these data are put up to date and presented in Table 1 and they allow the observation of different trends between Ponta Grossa and Castro zones.

The alumina represents an impurity in the talc ore. Some samples contain more than $8 \%$ of $\mathrm{Al}_{2} \mathrm{O}_{3}$. In these samples, it is accompanied by $2-3 \% \mathrm{Fe}_{2} \mathrm{O}_{3}$ which means the presence of other clay minerals as impurities. With $\mathrm{Al}_{2} \mathrm{O}_{3}$ higher than $4 \%$, the samples over burnt in $1450{ }^{\circ} \mathrm{C}$ ceramic tests, Loyola and Gondim (2000).

The Southern zone or Ponta Grossa zone exhibits a talc ore that is more lamellar, platy, unctuous, soft and more diversely associated to other minerals than the ore situated in Northern zone or Castro zone in which the talc is more powdery in its natural state.

Pressure during the metamorphism determines the crystallinity of the talc ore in the deposit (Luzenac, 2002). The surrounding pressure, either at the time of the metamorphic transformation or later, determines the mineral's degree of lamellarity (low pressure produces low lamellarity, high pressure produces high lamellarity) Eurotalc (2002).

The size of an individual talc platelet (a few thousand elementary sheets) can vary from approximately 1 micron to over 100 micra, depending on the genesis conditions of the deposit. The individual platelet size determines the talc's lamellarity; high lamellar talc will have large individual platelets whereas microcrystalline talc will have small platelets (Eurotalc, 2002). The talc from Castro zone tend to be more microcrystalline, and the talc from Ponta Grossa zone tend to be sparry.

Accord to the properties that present (see Table 1) and the ore beneficiating process, the talc ore from Ponta Grossa zone, commonly, has a possibility to be used in the industries of paint, paper, ceramics, cosmetics,

Table 1: Properties of talc ore in the two zones of the Paraná talc district.

\begin{tabular}{|c|c|c|}
\hline Property Zone & Ponta Grossa & Castro \\
\hline Platy & High & Low \\
\hline $\begin{array}{c}\text { Powder } \\
\text { (microcrystalline) }\end{array}$ & Low & High \\
\hline Associated minerals & Common & Not common \\
\hline $\begin{array}{r}\text { Major elements } \\
\text { present }(w t \%) \text { average }\end{array}$ & & \\
\hline $\mathrm{SiO}_{2}$ & 61,87 & 62,00 \\
\hline $\mathrm{Al}_{2} \mathrm{O}_{3}$ & 2,89 & 0,65 \\
\hline $\mathrm{Fe}_{2} \mathrm{O}_{3}$ & 1,47 & 0,56 \\
\hline $\mathrm{MgO}$ & 26,00 & 30,39 \\
\hline $\mathrm{CaO}$ & 0,61 & 0,30 \\
\hline L.O.I. & 6,73 & 5,85 \\
\hline \multicolumn{3}{|l|}{$\begin{array}{l}\text { Present Minerals } \\
\text { proportion average }\end{array}$} \\
\hline Talc & $\sqrt{ } \sqrt{ } \sqrt{ } \sqrt{ } \sqrt{ } \sqrt{ }$ & $\sqrt{ } \sqrt{ } \sqrt{ } \sqrt{ } \sqrt{ } \sqrt{ }$ \\
\hline Quartz & $\sqrt{\sqrt{ } \sqrt{ }}$ & $\sqrt{ }$ \\
\hline Chlorite & $\sqrt{\sqrt{ } \sqrt{ }}$ & $\sqrt{\sqrt{ }}$ \\
\hline Tremolite & $\sqrt{ }$ & \\
\hline Montmorillonite & $\sqrt{ }$ & \\
\hline
\end{tabular}

(Source Loyola 1987, actualized) 
plastics and rubber. Specifically for the ceramic industry, the talc ore from this zone, in which there are clay minerals associated, gives better resistance to ceramic products.

By the way, the talc ore from the Castro zone is more appropriate to be used in special ceramics and rubber industry. For the ore from Castro it is always possible to obtain the white color for ceramic, through the increase of the temperature, because this ore is more pure than Ponta Grossa talc. The presence of clay minerals reduces the burning point of ceramic.

\section{The São José talc deposit}

There is one deposit in the São José mine that belongs to the Ponta Grossa zone, that is one exception comparing with the other deposits in terms of its characteristics.

In this deposit the talc is relatively pure and present calcite in the paragenesis. There are several colors (rose, tan, gray and black) in the massive talc ore of the São José deposit. Samples of different color were selected and analyzed in terms of the main characteristics for

Table 2: Properties of the talc ore from São José Mine - Brazil.

(Analyses in Luzenac laboratory, Denver, USA)

\begin{tabular}{|c|c|c|c|c|}
\hline $\begin{array}{l}\text { ORE } \\
\text { TYPE }\end{array}$ & $\begin{array}{l}\text { \#5 Rose } \\
\text { ore }\end{array}$ & $\begin{array}{c}\text { \#6 } \\
\text { Tan ore }\end{array}$ & $\begin{array}{c}\# 7 \\
\text { Gray ore }\end{array}$ & $\begin{array}{c}\# 8 \\
\text { Black ore }\end{array}$ \\
\hline $\begin{array}{c}\text { Sedigraph } \\
\text { Median Particle } \\
\text { Size }(\mu \mathrm{m})\end{array}$ & 11.2 & 8.8 & 15.9 & 17.3 \\
\hline $\begin{array}{c}\text { Technidyne } \\
\text { Brightness } \\
\text { (GEB) }\end{array}$ & 93 & 94 & 86 & 47 \\
\hline \multicolumn{5}{|l|}{$\begin{array}{l}\text { Minolta } \\
\text { Color: }\end{array}$} \\
\hline $\mathrm{Y}$ & 94.1 & 94.7 & 86.1 & 44.8 \\
\hline Hunter L & 97.0 & 97.3 & 92.8 & 66.9 \\
\hline Hunter a & +0.4 & +0.2 & +0.01 & -0.03 \\
\hline Hunter b & +1.2 & +1.6 & +0.8 & +0.7 \\
\hline $\begin{array}{c}\text { Loss on } \\
\text { Ignition } 1050^{\circ} \mathrm{C} \\
(\%) \\
\end{array}$ & 5.0 & 5.1 & 13.5 & 21.4 \\
\hline \multicolumn{5}{|l|}{$\begin{array}{c}\text { Minerals } \\
\text { Present (\%): }\end{array}$} \\
\hline Talc & $>99$ & 99 & 77 & 58 \\
\hline \multicolumn{5}{|l|}{ Chlorite } \\
\hline Quartz & & & $<1$ & \\
\hline Calcite & & 1 & 22 & 32 \\
\hline Dolomite & & & $<1$ & 10 \\
\hline \multicolumn{5}{|l|}{$\begin{array}{c}\text { Major } \\
\text { elements } \\
\text { present }(w t \%):\end{array}$} \\
\hline $\mathrm{Al}_{2} \mathrm{O}_{3}$ & 0.22 & 0.23 & 0.34 & 0.22 \\
\hline $\mathrm{CaO}$ & 0.33 & 0.24 & 11.68 & 19.05 \\
\hline $\mathrm{Fe}_{2} \mathrm{O}_{3}$ & 0.03 & 0.10 & 0.08 & 0.05 \\
\hline $\mathrm{K}_{2} \mathrm{O}$ & 0.03 & 0.03 & 0.03 & 0.03 \\
\hline $\mathrm{MgO}$ & 30.27 & 30.24 & 23.37 & 20.13 \\
\hline $\mathrm{MnO}$ & 0.03 & 0.03 & 0.04 & 0.04 \\
\hline $\mathrm{Na}_{2} \mathrm{O}$ & 0.15 & 0.07 & 0.06 & $<0.01$ \\
\hline $\mathrm{P}_{2} \mathrm{O}_{5}$ & $<0.01$ & 0.01 & 0.01 & 0.02 \\
\hline $\mathrm{SiO}_{2}$ & 63.52 & 63.89 & 49.05 & 37.36 \\
\hline $\mathrm{TiO}_{2}$ & 0.22 & 0.23 & 0.34 & $<0.01$ \\
\hline
\end{tabular}


industrial use. Data of the analyses for each type of talc ore, selected by its color, are presented in Table 2.

The gray and black talc ores have calcite minerals associated. This is coherent with the data obtained in the analyses. Comparing the mean particle size, they are bigger in black and gray ore than the rose and tan ore. The brightness intensity has a small reduction in the gray ore and a great reduction in black ore.

The calcite, as associated mineral, difficults the use of this ore type in cosmetics. It needs to separate this mineral during the dressing process, because the calcite is not soft to touch. Nevertheless, this type of ore is appropriated to ceramic use due to the presence of calcite and the absence of clay minerals that is coherent with low percent of $\mathrm{Fe}_{2} \mathrm{O}_{3}$ and $\mathrm{Al}_{2} \mathrm{O}_{3}$ (Table 2).

\section{Properties and special use in polypropylene}

The talc ore in Ponta Grossa and Castro zone differ mainly in:

- Morphological structure (platy and powdery).

- Mineralogical composition.

These parameters command the specific nature of each commercial talc grade, that are employed in different uses in the industry including the polypropylene manufacturing. The thermal stability depends on the crystallinity/platyness of the talc ore, its specific surface and its chemical content. These characteristics are very important to the thermal degradation behavior of the different talc grades.

The talc ore to be used in polypropylene industry must be composed of sparry talc (platy, lamellar particles). In this way, this type of ore is more common in the Ponta Grossa zone, differently in the Castro zone the powder microcrystalline talc is more common (round particles formed by agglomerates of micrometers crystals). The platyness is an important factor that determines high stiffness and thermal stability, including high heat distortion temperature and high dimensional stability (low shrinkage, low thermal expansion coefficient).

The use for polypropylene industry also requires advanced milling technology to obtain the finest talc, however, it must avoid depleting the reinforcing power of their lamellar structure.

\section{Aknowledgements}

We would like to acknowledge the geologist David Crouse by the analyses of ore samples in Luzenac Laboratory in USA. Thanks to Tiago Rossi for the text revision. Thanks to the geologists Ricardo Dias and and Manoel Camlofski for discussion and exchange of information about the Paraná Talc District.

\section{References}

Eurotalc. 2002 What is talc.http:/www.ima-eu.org/en/ talcwhat.html.

Gondim A. C. 2000a Magnesite and talc in Brazil related to the world context. Mineralia Slovaca 32 (6):517-520.

Gondim, A. C. 2000b First field correlation - talc deposits of Paraná State. Curitiba: IGCP - 443, 14p.

Gondim, A. C. 2001 Exploration of talc deposits in Paraná State, Brazil. Mineralia Slovaca 33 (6): 575-578.

Lima, R.E. 1993 Evolução geológica e controles dos depósitos de talco da região Itaiacoca-Abapã/PR. Inst. de Geociência, UNB, Brasília, Dissertação de Mestrado, 139 p.

Loyola, L. C. 1987: Talco no Paraná: caracterização tecnológica. MINEROPAR, Curitiba.

Loyola, L. C. \& Gondim, A. C., 2000: Characterization of Paraná talc deposits, Brazil. Mineralia Slovaca, 32: 527-529.
Luzenac. 2002: Talc For The World - Talc geology. http:// www.luzenac.com/geology.htlm.

Luzenac. 2002 The mineraltalc. http://www.luzenac.com/ whatstalc.htlm.

Piniazkiewicz, R.J. 1984 Geology of and exploration techniques for Pre-Beltian talc deposits of the Malesiah Ranch, Ruby Range, Madison County, Montana, MS thesis, University of Arizona, Tucson, 101p.

Prochaska, W. 2000 Magnesite and talc deposits in Austria. Mineralia Slovaca, 32: 543-548.

Reis Neto, J. M. 1994 Faixa Itaiacoca: registro de uma colisão entre dois blocos continebtais no neoproterozóico.. I.G. - USP, São Paulo, Tese de Doutorado, 253 p.

Ribas, S. M, David, C. A. S., Brandão, W. \& Valaski, Z. de F. 1999: Avaliação metalogenética do distrito mineiro de talco no Estado do Paraná. MINEROPAR, Relatório inédito, Curitiba, v.1. 